\title{
COVID-19におけるTwitterの利用傾向に関する探索的研究
}

\section{Exploratory Research on Twitter Usage Trends of COVID-19}

\author{
渡邊憲二 ${ }^{1 *}$, 箕輪弘嗣 1 \\ Kenji WATANABE $^{1 *}$, Hirotsugu MINOWA ${ }^{1}$
}

\section{1 岡山商科大学}

Okayama Shoka University

₹700-0087 岡山県岡山市北区津島京町2丁目10-1

E-mail: k-watanabe@po.osu.ac.jp

*連絡先著者 Corresponding Author

COVID-19 が蔓延する中で, 社会的な変化だけでなく, 個人の生活や行動にも影響がみられて いる. そこで，人々の考えや社会的な反応を俯瞰することを目的として, Twitter のツイート内容から 得られる質的データに着目した. Twitter のツイートには, リアルタイム性が強く, 様々な情報や意見 を含んだ投稿が多い.このツイート内容から得られる質的データを解析することで, COVID-19 の今 後の対応や取り組みにも活用が可能となる.

本研究では, Twitter のツイート内容を対象に, テキストマイニングからツイート傾向を確認する. ま た, 新型コロナウイルス感染の拡大によるツイート内容の変化も検討する.

The spread of COVID-19 affects not only social changes but also personal lives and behaviors. Therefore, we focused on the content of Twitter with the aim of clarifying people's thoughts and social reactions. Twitter often posts various information and opinions in real time.By analyzing the contents of Twitter, it will be possible to utilize it for future correspondence and efforts for COVID-19.

In this study, we analyzed the contents of Twitter of COVID-19 from text mining. キーワード: COVID-19, Twitter, テキストマイニング

Keywords: COVID-19, Twitter, Text Mining

\section{1 はじめに}

2021年現在, 世界中でCOVID-19（以下， 「新型コロナウイルス感染症」と記載）の 拡大は続いている，新型コロナウイルス感 染症は，生命を劦かすことだけに留まらず， 各国の政治や経済にまで影響を及ぼし，さ らには人間の日常生活にまで変化をもた

$$
\text { らしている。 }
$$

日本国内では, 新型コロナウイルス感染 症感染者が2020年1月に初めて確認され， 新型コロナウイルス感染症の感染者数は 累計 23.4 万人 $(2020$ 年 12 月末）に達してい る.このように新型コロナウイルス感染者 が増加したことで, 2020年は政府による小 
中高校の臨時休校要請や東京オリンピッ ク・パラリンピックが延期となった。ささ に，自治体からの自肃要請や緊急事態宣言 発令等の異例な対応が続いている．個人の 生活では, 県外移動や不急外出の自肃だけ でなく，在宅勤務やテレワーク等の新しい 生活様式の導入も進んでいる.

新型コロナウイルス感染症が蔓延する 中で, 社会的な変化だけでなく, 個人の生 活や行動にも影響がみられている。 そこで, 人々の考えや社会的な反応を俯瞰するた めに, Twitterのツイート内容に注目する. Twitterのツイートには, リアルタイム性が 強く，様々な情報や意見を含んだ投稿が多 い。このツイート内容から得られる質的デ ータを解析することで, 新型コロナウイル ス感染症への今後の対応や取り組みにも 活用が可能となる.

Twitterのツイートを利用した災害時の 先行研究では, 村井 [1], 村井 [2], 河井・ 藤代 [3], 篠田ら [4]が東日本大震災を取り 上げ，ツイートの利用傾向やコミュニケー ション構造の検討, さらにはツイート内容 から社会状況や被災地の現状を把握する ことが行われている。榎本ら [5]や横田・ 山田［6]は，ツイートから災害時における 心理状態や行動を定量的に把握している. また, 峰滝 [7]は, 新型コロナウイルスの ツイート内容から緊急事態宣言の解除が もたらした影響を明らかにしている。

本研究では, コロナ禍における人々の話 題や意識を把握することを目的として， Twitterのツイート内容を対象に，テキスト マイニングから全体的なツイート傾向を 確認する。また，二時点間比較を用いて， 新型コロナウイルス感染の拡大によるツ イート内容の変化を検討寸る.

\section{2 日本における新型コロナウイルス}

\section{感染の動向}

ここでは，日本の新型コロナウイルス対 応の動向を概観する。 日本における新型コ ロナウイルス感染症の陽性者数を示した のが，図1である $[8]$.

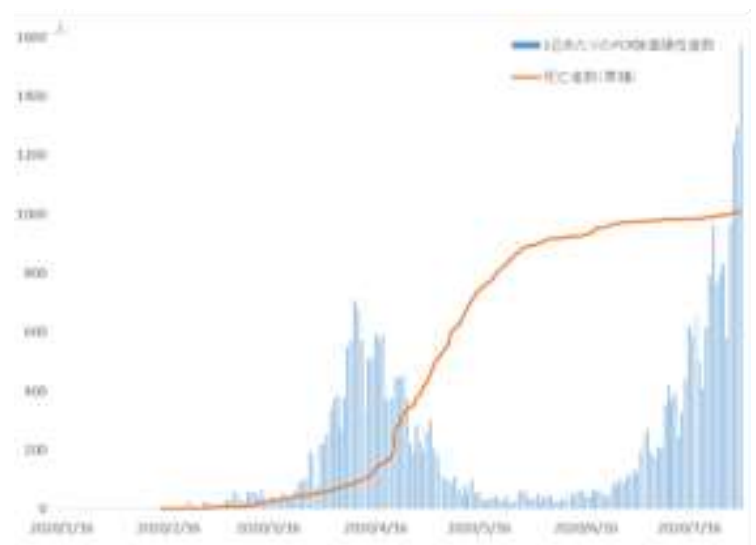

図1 日本における新型コロナウイルス感染 症陽性者数の動向

2020年1月 16 日に, 日本国内では最初の 新型コロナウイルス感染者の発生が確認 された．2月中旬から増え始め，3月下旬以 降に新型コロナウイルス感染者が急増し た。一日あたりのPCR検査陽性者数が3月 27日に100名を超え，4月10日では708名に まで拡大した。 その後, 4月下旬から緩や かに減少しつつ，5月下旬には収束してい る. そして，6月下旬から再び増加し始め, 6月28日には一日あたりのPCR検査陽性者 数が111名となり，7月末には1,000名を上 回ることになった，死亡者数をみると，国 内初の新型コロナウイルスによる死亡者 が2月13日に確認され，4月13日には 100 名 に達している。ささらに，4月下旬から急増 し，7月下旬には 1,000 名を上回った。こう した新型コロナウイルス感染者数の推移 
について，5月末までを第1波として，6月 からが第2波としている[9].

\section{3 データと分析手法}

データ収集に関して，Twitterのツイー トを収集するプログラミングコードを作 成し，新型コロナウイルス感染症に関す るツイートのみを収集するように対応さ せた。収集したツイートは, MySQL-DB へJSON-raw 形式で保存した。 なお, 現 在，低スペックのサーバで収集すること ができ，Excel/CSV 化が実時間で実現で きている.解析に用いるデータは, CSV(or Excel)形式へ変換(エクスポート)できる ように，エクスポートするプログラムは Python でコードを作成した。

本研究では，コロナ禍における Twitter のツイート反応から社会状況を把握する ために，二時点間比較によるアプローチ を行う。このアプローチを行うにあたっ $\tau$, 分析対象の日時 (以後,「分析日時」 と記載）を設定する必要がある。この分 析日時は，3つの基準から設定した。 基 準 1 は, 一日あたりの PCR 検查陽性者数 の動きである。これは，収束時期から新 型コロナウイルス感染者の増加によって, ツイート内容の変化をみるためである. 基準 2 は，政府から新型コロナウイルス 関連の発表や対応が行われた日時とした。 これは，時事的な話題や社会的な関心事 への反応をみるためである．基準 3 は, 二時点間比較の分析日時を 1 力月以内と することである。これは，季節性，生活 スタイル，社会状況などの定期的な動き や不規則な变化を極力抑えるためである. こうした 3 つの基準から，分析日時は 6 月 $19 \cdot 20$ 日と 7 月 $10 \cdot 11$ 日の各 2 日間
で，曜日は金曜日と土曜日とした。

分析日時の状況として, 6 月 $19 \cdot 20$ 日では，一日あたりの PCR 検査陽性者数 は 54 人 $(6 / 19)$ と 65 人 $(6 / 20)$ で，新 型コロナウイルス感染者数は下げ止まっ た時期である。また，6月 19 日は，全国 的に県外一の移動自肃が解除されただけ でなく，新型コロナウイルス接触確認ア プリ（COCOA）がリリースされている. 次に， 3 週間後の 7 月 $10 ・ 11$ 日は，一日 あたりの PCR 検査陽性者数は 420 人

（7/10）と 373 人（7/11）まで急増した 時期である． 7 月 10 日は，観光庁から GOTO トラベルの概要が発表された.

収集したツイート数は， 6 月 $19 \cdot 20$ 日が 1,361 件で， 7 月 $10 \cdot 11$ 日が 1,675 件であった，収集したツイートは，分析 の精度を高めるために，データのクレン ジングを行った。クレンジングの対象と して,「RT(retweet)」,「@tweet」,「URL」, 「重複している tweet 広告」, 「記述記号」 は削除した．分析に使用するサンプル数 （以下，「分析データ」と記載）は，それ ぞれ 1,219 件 (6月 $19 \cdot 20$ 日)，1,265 件（7月 $10 \cdot 11$ 日）となった。

分析には，テキストマイニング解析ソ フト KH Coder（3.Beta.02c）を使用し ている. KH Coder を利用して, 分析デ 一タを MeCab で形態素解析を行った。 出現頻度の高い単語については，コーデ イング(表記摇れを含む)を定めている. 出現頻度が低い（10 回以下）単語は，コ ーディングならびに表記摇れから除外し ている. 分析対象のコーディングは, 表 1 に示した. 出現回数が多い単語につい ては，表 2 のとおりである. 
表1 分析対象のコーディング

\begin{tabular}{|c|c|}
\hline コード名 & コーディングによる分類(表記摇れを含む) \\
\hline 新型コロナ & 新型コロナ, コロナ, COVID-19, COVID, SARS-CoV, SARS-COV, 新型肺炎 \\
\hline 検査 & 検査，PCR，PCR検査 \\
\hline ウイルス & ウイルス, ウィルス \\
\hline 日本 & 日本, JAPAN, japan, nihon \\
\hline 今日 & 今日, 本日, 今, 現在, now \\
\hline クラスター & クラスター, 集団 \\
\hline COCOA & COCOA, ココア, ココアアプリ, COVID-19 \\
\hline インストール & ダウンロード, インストール \\
\hline 政府 & 政府, 国 \\
\hline 死亡 & 死亡，亡くなる，死者，死ぬ \\
\hline NEWS & ニュース, NEWS, News, news \\
\hline 都知事 & 都知事，小池，小池都知事 \\
\hline GOTO & GOTO, Go to, ゴートゥー \\
\hline トラベル & トラベル, travel, 旅行, Travelキャンペーン \\
\hline 第2波 & 第2波，第二波，2波，二波 \\
\hline 楽天市場 & 楽天, 楽天市場 \\
\hline
\end{tabular}

表2 出現回数の多い単語リスト

\begin{tabular}{|c|c|c|c|}
\hline \multicolumn{4}{|c|}{ 出現回数の多い単語 } \\
\hline \multicolumn{2}{|c|}{ 6月19·20日のツイート } & \multicolumn{2}{|c|}{ 7月10・11日のツイート } \\
\hline 単語 & 出現回数 & 単語 & 出現回数 \\
\hline 新型コロナ & 2008 & 新型コロナ & 2000 \\
\hline ウイルス & 456 & 感染 & 648 \\
\hline 感染 & 411 & ウイルス & 303 \\
\hline マスク & 316 & 東京 & 294 \\
\hline アプリ & 207 & 人 & 189 \\
\hline 確認 & 184 & トラベル & 165 \\
\hline 人 & 176 & マスク & 142 \\
\hline 接触 & 155 & 今日 & 136 \\
\hline 今日 & 140 & 検査 & 129 \\
\hline 対策 & 124 & GOTO & 117 \\
\hline 日本 & 115 & 思う & 109 \\
\hline COCOA & 114 & 対策 & 108 \\
\hline 楽天市場 & 93 & 言う & 107 \\
\hline 東京 & 79 & 増える & 96 \\
\hline 厚生労働省 & 78 & 日本 & 86 \\
\hline 自萧 & 73 & NEWS & 84 \\
\hline 6月 & 72 & 政府 & 78 \\
\hline 検査 & 68 & 確認 & 76 \\
\hline インストール & 67 & 死亡 & 74 \\
\hline 死亡 & 66 & 緊急事態宣言 & 66 \\
\hline お金 & 61 & 出る & 66 \\
\hline 情報 & 61 & 自萧 & 64 \\
\hline 思う & 60 & 経済 & 61 \\
\hline 予防 & 53 & 拡大 & 57 \\
\hline 副業 & 52 & 都知事 & 56 \\
\hline 言う & 51 & 陽性 & 55 \\
\hline 無料 & 51 & 自分 & 53 \\
\hline 負ける & 50 & 新た & 52 \\
\hline 在庫 & 49 & 7月 & 51 \\
\hline
\end{tabular}

出現回数の多い単語として,「新型コロ ナ」,「ウイルス」,「感染」が挙げられる. 6 月 $19 \cdot 20$ 日から 7 月 $10 \cdot 11$ 日の動き をみると，「マスク」は大きく減少してい るものの, 「検査」,「増える」,「拡大」, 「陽性」といった単語は出現回数が増え ている．また，政府が関わる内容につい て, 6 月 $19 \cdot 20$ 日では「アプリ」,

$\lceil\mathrm{COCOA}\rfloor$, 「厚生労働省」,「インスト ール」といった単語が多く確認され，7
月 $10 ・ 11$ 日では「トラベル」,「GOTO」 といった単語が増えている。こうしたこ とから，Twitterのツイートは，新型コロ ナウイルス感染症の話題だけでなく, 時 事的な話題や社会的関心事にも一時的に 強く反応していることが窥える.

\section{4 分析結果}

ここでは，MDS（多次元尺度構成法） と共起ネットワークを用いて，Twitter に よるツイートの利用傾向や社会状況を把 握する. MDS は, 単語間の類似性や相違 性を視覚化することができる分析である. 特徴としては，原点付近にプロットされ た場合は、ツイートで一般的に使われた 単語といえる。また，原点からの距離が 離れるほじ，特徴的な単語であるといえ る。そして，単語間の関係が強い場合に は単語が近くに集まり，関係が弱い場合 には離れてプロットされる. バブルのサ イズは，出現回数が多いほど大きな円と なる，共起ネットワークは，出現パター ンの類似する単語の共起関係がみてとれ る. 共起ネットワークで結ばれていれば, 同じツイート内で使われており，単語間 の関連性が強いといえる。また，共起関 係の強弱は，Jaccard 係数で判断すること ができる.

MDS と共起ネットワークによる分析 結果は，それぞれ図 2 と図 3 である。図 2 は， 6 月 $19 \cdot 20$ 日の結果であり，8つ のクラスターが確認された。 原点には,

「新型コロナ」があり，その周囲には「ウ イルス」や「感染」といった単語が集ま っている。第一象限には,「検査」,「陽 性」, 「死亡」等の新型コロナウイルス感 染結果に関する単語がみられる。第二象 
限には,「COCOA」,「アプリ」,「政府」 等の行政に関する単語が確認された。第 三象限では，「仕事」，「在宅」，「自肃」等 の日常生活に関する単語である．第四象 限は，「楽天市場」や「販売」等の EC に 関する単語が集まっている。

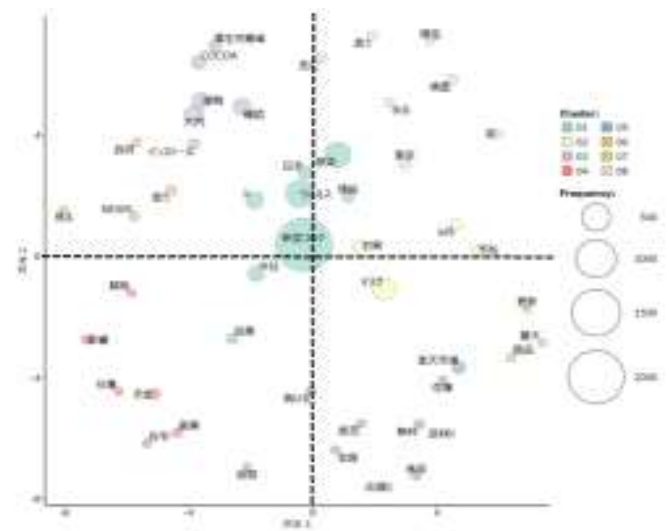

図 2 MDS の分析結果 $(6 / 19 \cdot 20)$

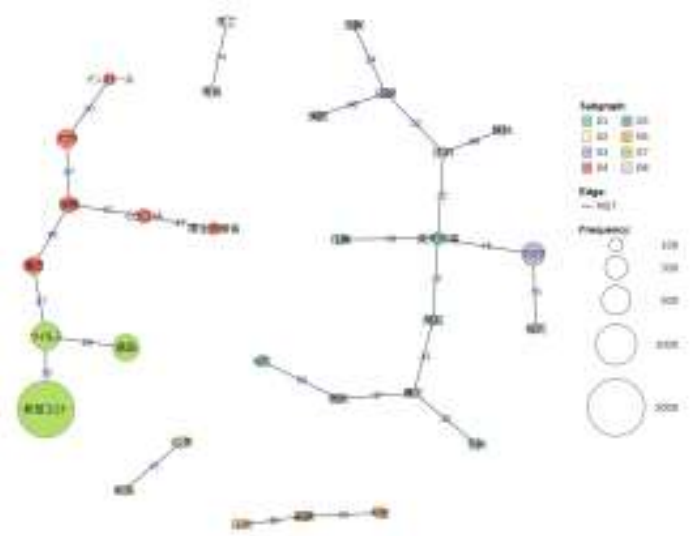

図 3 共起ネットワーク $(6 / 19 \cdot 20)$

共起ネットワークに関して, ツイート 内容をみると, 中規模程度の話題が $2 つ$ 確認されている。一つは，「新型コロナ」 と新型コロナウイルス接触確認アプリ

（COCOA）の関連が挙げられる。もう一 つは，「楽天市場」を通した食品やマスク の販売ならびに在庫に関する話題であっ た。また，「自肃一解除」や「在宅一副業 一お金」の日常生活に関するツイートも みてとれる。
これらのことから，ツイートの利用傾 向として，時事的な内容が多くツイート されていることがみてとれる。また，行 政の発表や対応だけでなく, 日常生活の 話題も確認された。特に，コロナ禍によ る新たな生活スタイルを表す多様な話題 がツイートされていることが確認された。

次に, 図 4 と図 5 は 7 月 $10 ・ 11$ 日の 結果である。図 4 では，9つのクラスタ 一がみられた。原点には，「新型コロナ」 の単語を中心に,「東京」,「感染」「ウイ ルス」,「増える」等の単語が近くにみら れている。第一象限には，「GOTO」，「ト ラベル」,「政府」等の行政に関する単語 が集まっている.第二象限には，「発表」,

「NEWS」，「更新」といった報道に関す る単語がみられた。第三象限には，「検 査」,「陽性」,「研究」,「結果」,「クラス ター」等の新型コロナウイルスの発生や 調査に関する単語が確認できる，第四象 限には，「第 2 波」，「来る」，「マスク」,

「対策」，「仕事」，「生活」，「影響」等の 生活様式や今後の動向に関する単語が現 れている.

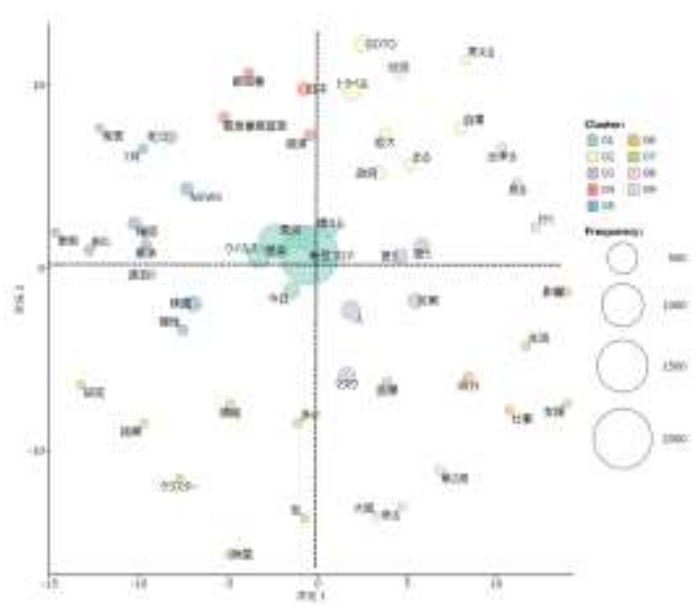

図4 MDSの分析結果 $(7 / 10 \cdot 11)$ 


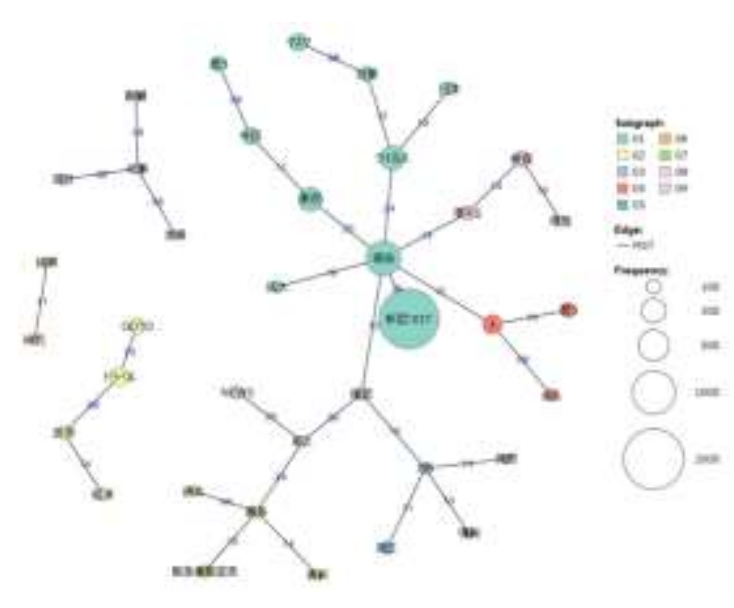

図5＼cjkstart共起ネットワーク（7/10・11）

共起ネットワークについて, 図 5 では, 「新型コロナー感染」を軸にした単語の 繋がりが大きくなっている.特に，「感染 一東京」,「感染一ウイルスー対策」,「感 染一増える一検査一陽性」といった単語 の繋がりが多くみられる。また，「GOTO 一トラベルー政府一経済」といった政策 に関する単語も比較的多く出現している. 加えて，仕事に関する共起関係のネット ワークもみられた。

これらのことから, ツイートの話題とし て, 新型コロナウイルス感染に関する報道 や情報が多くみられている。 また，共起市 ットワークでは，「新型コロナ一感染」が 話題の中心となっており，新型コロナウイ ルスの懸念や猛威を関する話題が多くを 占めている。興味のある時事的な話題とし て，GOTOトラベルの概要が発表されたこ とや生活不安のツイートも比較的確認す ることができた. 感染者数の増加に伴う状 況変化から，今後の動向を意識するような 話題が出現していることが推察される.

\section{5 まとめ}

本研究では，コロナ禍における人々の 話題や意識を把握することを目的として，
Twitterのツイート内容を対象に，テキス トマイニングから全体的なツイート傾向 を確認した。また，二時点間比較を用い て，新型コロナウイルス感染の拡大によ るツイート内容の変化を検討した。 得ら れた知見は，以下のとおりである.

形態素解析から，新型コロナウイルス 感染症が収束している時期では，政府の 対応に関わる時事的な話題や単語が多く 確認された。新型コロナウイルス感染者 数が増加している時期では,「検査」,

「増える」,「拡大」,「陽性」といった単 語の出現回数が増え, 新型コロナウイル ス感染症の拡大の話題が多く表れている. また, 政府が関わる内容について,「トラ ベル」,「GOTO」といった単語が増えて いる、こうしたことから，Twitterのツイ ートは新型コロナウイルス感染症の話題 だけでなく，時事的な話題や社会的関心 事にも一時的に強く反応する傾向が窺え た.

分析結果から, 共通の話題として, 新 型コロナウイルス感染に関する報道や情 報が多くみられた。さらに，政府の発表 や対応だけでなく, 日常生活の話題も確 認された. 感染者数の増加に伴う状況変 化として，今後の動向を意識するような 話題が比較的多く出現していた.

共起ネットワークでは, 新型コロナウ イルス感染症が収束している時期では, 時事的な内容が多くツイートされている ことがみてとれた。特に，コロナ禍によ る新たな生活スタイルを表す多様な話題 がツイートされていることが確認された。 一方で, 新型コロナウイルス感染者数が 増加している時期では，新型コロナウイ ルスの懸念や猛威を表すツイートが多く 
を占めているものの, 時事的な内容や生 活不安の話題も比較的多かった。

最後に，本研究では，コロナ禍におけ る人々の話題や意識について，二時点間 比較による探索的なアプローチを行った に過ぎない，今後の課題として，継続的 にデータ収集をしていくことで，より詳 細な分析が可能である。このことを踏ま え，他稿に譲りたい。

\section{参考文献}

[1]村井源：「東日本大震災後のTwitter利用 傾向一震災関連ハッシュタグの計量的分 析一」，情報知識学会誌，Vol. 22，No.2， pp.97-106, 2012.

[2]村井源：「東日本大震災でのTwitterハッ シュタグの利用傾向調査一震災時のICT活 用に向けて一」, 情報知識学会誌, Vol. 23,

No.3, pp.355-370, 2013.

[3] 河井孝仁 ; 藤代裕之：「東日本大震災 の災害情報におけるTwitterの利用分析」， 広報研究，第17号，pp. 118-128，2013. [4]篠田孝祐 ; 榊剛史 ; 鳥海不二夫 ; 風間 一洋 ; 栗原聡 ; 野田五十樹 ; 松尾豊 : 「東
日本大震災時における Twitter の活用状況 とコミュニケーション構造の分析」, 知能 と情報, Vol. 25, No.1, pp.598-608, 2013. [5]榎本甫; 桑野将司; 小池淳司 : 「災害 時のソーシャルメディアと帰宅行動の関 連性分析」，土木学会論文集D3（土木計画 学), Vol. 70, No. 1, pp.102-112, 2014. [6]横田尚己 ; 山田圭二郎：「熊本地震の つぶやきに見る感情極性值の時空間解析」, 都市計画論文集，Vol.52，No.3，

pp.1081-1087, 2017.

[7]峰滝和典：「Twitterデータを利用した 「新型コロナウィルス」関連語句の分析」 商経学叢, Vol.67, No.1, pp.195-219, 2020 .

[8] 厚生労働省 : 新型コロナウイルス感染 症について

https://www.mhlw.go.jp/stf/seisakunitsuite/bun ya/0000164708_00001.html（2021年04月08 日参照)

[9]鈴木基 : COVID-19の致命率と重症化リ スク因子について, 2020 https://www.mhlw.go.jp/content/10900000/00 0662183.pdf（2021年04月08日参照） 